\title{
Incoherence and incompatibility in planning law
}

Article

Accepted Version

Lees, E. and Shepherd, E. (2015) Incoherence and incompatibility in planning law. International Journal of Law in the Built Environment, 7 (2). pp. 111-126. ISSN 1756-1450 doi: https://doi.org/10.1108/IJLBE-07-2014-0019 Available at https://centaur.reading.ac.uk/68138/

It is advisable to refer to the publisher's version if you intend to cite from the work. See Guidance on citing.

To link to this article DOI: http://dx.doi.org/10.1108/IJLBE-07-2014-0019

Publisher: Emerald

All outputs in CentAUR are protected by Intellectual Property Rights law, including copyright law. Copyright and IPR is retained by the creators or other copyright holders. Terms and conditions for use of this material are defined in the End User Agreement.

\section{www.reading.ac.uk/centaur}

\section{CentAUR}

Central Archive at the University of Reading

Reading's research outputs online 


\title{
ACCEPTED VERSION, AUTHORS' POST-PRINT VERSION
}

\section{INCOHERENCE AND INCOMPATIBILITY IN PLANNING LAW}

\author{
Emma Lees \& Edward Shepherd
}

Accepted for International Journal of Law in the Built Environment on 10.10.2014

Keywords: planning law, localism

\section{Abstract}

Recent developments in planning law in England have produced a legal framework which relies upon localism and a presumption in favour of sustainable development. The former goal is achieved through the primacy given to a local development plan: the latter through the guidance in the National Planning Policy Framework. These obligations are internally incoherent, but they also produce incoherence when they operate simultaneously. This springs from a lack of commitment to any one understanding of the terms used, to the competing ideologies behind them, and to the scale and space within which these policies are to be given force.

Planning policy conceals this lack of coherence by relying on reasonableness and balance to achieve practical and sensible outcomes. When this is brought into a legal context however, and rendered justiciable, the masking of the incoherence is no longer effective, and legal problems result. This paper discusses these legal problems and demonstrates this incoherence. Planning decision-makers are required, as a result of these difficulties, to reconcile the irreconcilable, and to operate in the face of an uncertain and unpredictable legal position.

\section{Introduction}

Following the election of a Conservative/Liberal Democrat coalition government in England in 2010, significant reforms to the planning system have been introduced. These reforms followed a sustained attack from the Conservatives on planning under New Labour, which was characterised as being overly bureaucratic, overly centralised and anti-development (Conservative Party 2010). The subsequent changes have thus included the reduction in volume of national planning policy guidance, the removal of the regional tier of planning policy, and the introduction of a 'presumption in favour of sustainable development' which is now seen as "a golden thread running through both plan-making and decision-taking" (United Kingdom, 2012b [14]). These reforms are bound together by the overarching Conservative ethos of 'localism', characterised by the attempt to devolve more power to local areas and a supposed end to 'top-down' planning.

One result of these reforms is that three strands now clearly dominate the current agenda for English planning: reduction of 'regulatory burdens' (United Kingdom, 2014b) and increased flexibility where such burdens are unavoidable; maintenance of a high level of environmental protection without stifling development (United Kingdom, 2013); and localised decisionmaking (United Kingdom, 2012a; United Kingdom, 2012b). These policy themes are easily identified, but are they easily justiciable?

It is the argument of this paper that, when considered as standalone legal obligations, there are significant problems with the changes to and objectives for planning as set out above in terms of the three dominating strands: the definitions of both local and sustainable development are unclear, and the conferral of autonomy onto local decision-makers is ambiguous at best. When combined, however, incoherence and incompatibility arises. Ultimately, these policies seek to achieve nationally mandated goals on a local basis (Taylor, 
2013, p. OP12). This simultaneously attempts to grant autonomy to local decision-makers, whilst controlling that 'autonomy' to ensure it allows for sustainable development on a national level. Just as environmental law and 'localism' make for uneasy bedfellows (Lees, 2014), so too do the presumption in favour of sustainable development and the overarching ethos of localism. This paper explores these tensions, their manifestations in planning law and their impact on decision-makers who are obliged to reconcile the irreconcilable.

It does so by firstly briefly reviewing some of the literature discussing the underlying inconsistency and incoherence that persist in planning. This review demonstrates that planning policy, which is intended to operate in practice in a coherent way, cannot do so as a result of incoherence which manifests in a lack of commitment to a clear understanding of core concepts, to a single ideology, or to how power should be distributed through space or scale.

The paper then tests this reading of the literature by investigating how the currently dominant policy themes play out in English practice, with a particular emphasis on the decisions of the English courts. The evidence suggests that through its reliance on 'sensible' decision-makers and reasonableness in making policy decisions, English planning policy appears at first reading to be successful in masking its own internal incoherence. Unfortunately, as will be seen, once this policy is transformed into legal obligations through contact with the courts, its incoherence is exposed. Individual legal decisions may seek to repair the faults which have been identified through the deliberative process, but when individual legal decisions are viewed together, the collective inconsistency of the legal framework that arises is exposed. This process at the judicial level will be discussed in relation to localism and sustainable development. It will be argued that as standalone policies they become incoherent legal obligations, and when combined, the problem becomes not just one of incoherence, but also of incompatibility.

\section{Incoherence and incompatibility in planning}

The following brief review of the planning literature demonstrates that incoherence and incompatibility have emerged as significant themes in analyses of planning in England. Three broad concerns in the theoretical debate which are of relevance to this paper are identified: (a) ambiguity of core concepts in planning; (b) ideological contradiction in planning; and (c) spaces and scales of planning in the nation state.

\subsection{Ambiguity of Core Concepts}

"It is not new to point out that many of the central concepts in planning theory and practice are imprecise, vague, ambiguous, and opaque" (Taylor, 2003, p.92). Whether it be 'community', 'regeneration', 'sustainable development', 'policy integration', 'localism' or any other 'concept du jour', planning theory, policy and practice is loaded with words and concepts which are neither coherently defined nor consistently interpreted, understood or applied (e.g. Cochrane, 2003; Davoudi, 2000; Furbey, 1999; House of Commons, 2011; Stead \& Meijers, 2009; Taylor, 2003).

This suggests that there is a risk that this lack of clarity over the meaning of core concepts in planning will lead to multiple, variable and incommensurable readings and applications of policy: in the context of such confusion and (sometimes deliberate) obfuscation, how can planning be a coherent process? There is therefore an anxiety in the literature regarding the imprecision of the language of policy and the related potential for the incoherence of the interpretation of core planning concepts in practice.

When policy remains un-tested by law such issues can remain hidden beneath the surface of language. By using the examples of 'sustainable development' and 'localism', this paper 
demonstrates that when the flexible language of policy is exposed to the interpretative power of the courts, its latent inconsistency and incoherence is exposed as the law is forced to try and reconcile the irreconcilable. Of course, in coming to a decision, a prioritisation must be made and a particular ideological position may be given prominence over its competitors.

\subsection{Ideological Contradiction}

Some of the literature suggests that planning policy and law internalises tensions between competing and sometimes conflicting ideological positions. Foley was one of the first and noted a risk that should these inconsistencies become too "imbedded", then they may undermine any chances of planning in Britain achieving any "coherent rationale" (Foley, 1960 , p. 227). This theme of ideological conflict in planning has been repeatedly returned to in the literature (e.g. Adshead, 2014; Fagence, 1983; Guttenberg, 2009; McAuslan, 1980; Reade, 1983; Taylor, 1980; Tewdwr-Jones, 1999).

McAuslan's assessment of the ideologies of English planning law is of particular relevance to this paper. Over 30 years ago, he identified three distinct and competing ideological perspectives in UK planning law: a) that the law should be used to protect private property; b) that the law should advance the public interest; and c) that the law should be used to advance public participation (McAuslan, 1980, p. 2). For McAuslan, the conflict between these competing ideologies in planning law were "one of the causes of the general disarray in, and disillusion with, the planning system" (ibid, p. 6).

It is perhaps testament to the strength of McAuslan's analysis (and also to the institutional and ideological resilience of UK planning law) that Adshead in her recent update to McAuslan's work felt able to conclude that, "little has changed in the balance between these three legal ideologies and McAuslan's overarching conclusions, at least in respect of the law and guidance on development control, remain good today" (Adshead, 2014, p. 192). However, McAuslan's three ideologies should not blind us to other potential ideological themes in UK planning law. It is beyond the scope of this paper to unearth all possible candidates, but there are arguably also ideological themes in English planning concerning scales and spaces of governance which are partly manifested in the problematic concepts of 'sustainable development' and 'localism' with which this paper is concerned.

Aside from McAuslan, the literature also emphasises the potential for contradiction and ideological incoherence in the European 'spatial planning' project, which emphasises an integrated, consensus-based approach to meeting multiple cross-sectoral priorities and agendas. Spatial planning has been criticised for its hubris in seeking to simultaneously meet the objectives of multiple and competing agendas (as typified in the problematic and internally inconsistent concept of 'sustainable development'), as well as for its post-political suppression of agonism through a focus on achieving a problematic and fragile consensus which in fact prioritises particular interests (e.g. Allmendinger \& Haughton, 2010, 2012; Buser \& Farthing, 2011).

This discussion of ideological conflict in the planning literature therefore suggests that decision makers in England face the difficult challenge of reconciling competing ideological agendas, while potentially at the same time being influenced by their own ideological biases, thereby giving conscious or unconscious priority to one over another. Freeden's 'morphological' conception of ideology is helpful here, as it offers a way to think about ideology as functioning to 'decontest' political concepts by "cementing the word-concept relationship" (Freeden, 1998, p. 76), thereby shutting out alternative interpretations through the exertion of control over meaning. For Freeden, ideologies "straddle the worlds of political thought and political action" and serve as the "bridging mechanism between contestability and determinacy" (ibid). In the context of the English courts, it is legal decisions themselves 
which convert planning concepts from contestable to determinate and prompt specific planning action.

This paper brings these themes to bear on cases which demonstrate that decisions made under 'localism' and in supposed compliance with the 'presumption in favour of sustainable development' are riven with ideological competition and contradiction. The result is a legal framework comprising individual decisions prioritising one or the other which, when taken together, produces incoherence.

\subsection{Spaces and Scales of Planning}

Closely related to discussions of spatial planning in England, the literature also focuses on incoherence arising from the conflict between different scales of planning policy, particularly the national and the local. This can be seen as part of a broader debate about scales of governance and the locations of political power in the nation state (MacLeod \& Goodwin, 1999), which in policy terms has been manifested in the Coalition's up-dated brand of 'localism' (Conservative Party, 2010; HM Government, 2010; Localism Act, 2011).

It has been argued by Hickson that localism can be seen as a "radical ideological critique" of the central state (Hickson, 2013, p. 408), but is based on a conceptual misunderstanding which holds that power can be 'positive sum', non-hierarchical, and may therefore be dispersed widely without losing its value. In fact, Hickson argues, it is more likely that power is 'zero sum', cannot therefore be dispersed, and more often than not takes the form of 'power over' in society and the economy, rather than 'power to' (ibid, p. 419). Localism as a concept may therefore be internally conflicted and incoherent as it is based on a flawed understanding of the nature of political power.

Issues relating to scales of planning go beyond a simple national/regional/local typology of scale. The emergence of 'soft spaces' of governance and planning (Allmendinger \& Haughton, 2009; Allmendinger et al, 2014) has exposed a further level of incoherence in the form of a disentanglement of practical planning processes from the system of formal statutory plans, potentially resulting in an uneven and fragmentary system in which the formality of the plan jostles against the relative informality of planning in practice (Haughton et al, 2013).

This suggests that unresolved tensions between spaces and scales of planning may give rise to a policy and legal framework for planning which is not coherent. Tensions over the desired degree of local autonomy, over local participation, and the processes by which that is achieved, may pointedly manifest themselves once the policy which attempts to work around these problems becomes law.

\subsection{Summary}

An overarching narrative binds these three themes together. It is the one which holds that planning is not a science and, as such, it deals with what Rittel and Webber have called 'wicked problems' to which there are no solutions "in the sense of definite and objective answers" (Rittel \& Webber, 1973, p. 155). However, it is paradoxically the role of the courts to provide such 'definite and objective' answers to questions of planning law on a case by case basis. This conflict between the very nature of planning as an activity, and the nature of the legal process is therefore prone to give rise to contradiction and incoherence in the resultant legal framework.

Nevertheless is through the process of decision-making regarding the appropriate application of planning policy and law that the sometimes woolly concepts enshrined in legislation and policy are honed into a usable form, any ideological influence thereby crystallised, and the tensions between spaces and scales of governance addressed in practice. But in so doing, 
decision-makers give priority to certain interpretations of core planning concepts, thereby emphasising one of a number of competing ideological positions, and endorsing a particular articulation of power through the state.

This process will now be examined at the judicial level through the lens of 'localism' and the 'presumption in favour of sustainable development' in contemporary English planning. It will be demonstrated that it is partly through this process that the incoherence and incompatibility of planning policy suggested by the literature is manifested. These underlying issues are revealed through the deliberations underpinning legal decisions based upon these policies. This will happen no matter how much the courts attempt to plaster over the deep-rooted incoherence by relying on concepts such as balance, and reasonableness.

\section{Localism}

Localism has come under criticism for attempting to impose nationally mandated goals under the guise of local decision-making (Allmendinger and Haughton, 2011; Layard 2012; Taylor 2013). How is a decision "local" if it is designed to ensure that national targets are met (Taylor, 2013, p. OP12)? Furthermore, "local" is defined administratively, not according to criteria relevant to a planning decision (Layard, 2012 p. 136; Localism Act 2011, section 1(1)). Such criticisms are well made, and suggest that localism is a focal point for the debate around appropriate spaces and scales of planning.

These criticisms can be addressed, however, by highlighting that questions of planning are questions of balance, a balance to be struck by each individual decision-maker (Taylor, 2013, p. OP12). ${ }^{[1]}$ Local autonomy can be balanced with national goals, for example through insistence as to ends, but flexibility as to means. The ideal of a flexible definition of "local" too must be balanced against the need to distribute scarce resources and a desire to avoid paralysing administrative complexity. Thus, in theory, inconsistency and incoherence internal to the concept of localism can be covered over by planning decision-makers exercising their 'reasonable judgment'.

Localism becomes law through the "presumption" of the primacy of a local plan in reaching individual planning decisions. ${ }^{[2]}$ National guidance, which of course forms a critical backdrop to such a decision, is relegated to the status of "material consideration". ${ }^{[3]}$ The local plan should only be departed from if material considerations, when taken together, outweigh the policies and justifications that themselves went into the creation of that local plan. Most importantly, the material consideration of the national guidance must also be seen to outweigh a local plan which, in a sense, has already explained its reasons for departing from national guidance, and been found to be satisfactory in so doing, by the Planning Inspectorate. The local plan, under section 19, must have regard to national policy. It does not need to comply with that policy. Nevertheless, there must be convincing reasons demonstrated to the Planning Inspectorate for the departure to be justified, and for the plan to be found to comply with section 19. Therefore national guidance must (theoretically) be "doubly potent" in order to rebut the presumption that the local development plan be followed since any departure has already been found to be justified.

Thus, as Lewis $\mathbf{J}$ reasons in South Northamptonshire Council v Secretary of State for Communities and Local Government when discussing the impact of the NPPF upon a development plan:

[1] Cala Homes v SSCLG [2011] EWHC 97 (Admin) at [48]; Colman v DCLG [2013] EWHC 1138 (Admin) at [57].

${ }^{[2]}$ Planning and Compulsory Purchase Act 2004, section 38(6).

${ }^{[3]}$ D B Schenker Rail (UK) Ltd, Towngate Estates Ltd v Leeds City Council [2013] EWHC 2865 (Admin). 
It is not saying that you can disregard the whole development plan and simply apply the Framework. Firstly, as a matter of law, of course, the Framework could not do that... Secondly, the Framework cannot of itself provide that provisions of a development plan are no longer applicable.... However, the Framework is a material consideration. The factors to which it refers may be material considerations that indicate that planning permission should be granted, even though that would conflict with the development plan. That may be particularly the case if the development plan is, in fact, out of date and is not meeting current needs. ${ }^{[4]}$

In other words, the presumption in favour of the local plan expressed in section 38(6) cannot be overridden by the NPPF, and it is only if it can be shown that local needs are not being met, for example, that the national policy within the NPPF can be called upon to override that local plan. The NPPF is invoked when local needs demand it. Hickinbotton $\mathrm{J}$ in $R$. (on the application of Midcounties Co-operative Ltd) $v$ Swindon BC too confirms the primacy of the development plan. ${ }^{[5]}$ Similarly, in Chase Milton Energy Ltd $v$ Secretary of State for Communities and Local Government, Straker QC states that, "the framework cannot, of course, alter the statutory required approach to decision making". ${ }^{[6]}$ "Local" (however defined), in this sense, retains its prime status.

The problems of localism as a policy however do have impacts upon the coherence of this presumption. These problems undermine the presumption in favour of the local plan to such an extent that its status as a "presumption" can be called into question. As Taylor (2013, p. OP12) highlights:

There is a view about amongst some MPs and councillors that localism means that councils are empowered to ignore any government's wish for 'sustainable development' and, where there is opposition to development, to minimise it all over again. Were this true, the NPPF would be disastrously wrong... Fortunately, it is not true.

He thus argues that the legal structures have been set in place in order to avoid the theoretical problems with localism resulting in the stifling of necessary development and preventing the creation of workable legal structures. The "presumption" in favour of the local plan is to be balanced against the presumption in favour of sustainable development (Taylor 2013, p. OP12). Bird (2013, p. OP85) agrees with this approach stating that "experience is showing that there are some issues which do not lend themselves to local approaches and where a clear steer from higher order policy is required".

But this policy balance, and the nuance that Taylor (2013) portrays as existing, is not replicated in the legal framework. Indeed, such a balance would be very hard to capture in legal terms. How does one legally oblige a decision-maker to not 'wish issues away'? It is not possible to balance compliance with law with compliance with policy goals, however hard the process of judicial review tries to achieve such an outcome. The attempt to transform localism into law is therefore riddled with inconsistency in the case law and in planning appeal decisions. The more binary nature of legal decisions reveals the internal incoherence of localism as a policy. The courts, as a result, are struggling to articulate the precise effect of the NPPF on policies contained within local plan, resorting simply to statements of 'balancing'. This is demonstrated in Chase Milton. ${ }^{[7]}$ As Straker QC states: "it could be necessary for a local planning authority in a case where policies fall in different directions to

[4] South Northamptonshire Council v Secretary of State for Communities and Local Government [2013] EWHC 4377 (Admin) at [23]-[24].

${ }^{[5]} R$. (on the application of Midcounties Co-operative Ltd) $v$ Swindon BC [2013] EWHC 3775 (Admin) at [22].

[6] Chase Milton Energy Ltd v Secretary of State for Communities and Local Government [2014] EWHC 1213 (Admin) at [10].

${ }^{[7]}$ Chase Milton Energy Ltd v Secretary of State for Communities and Local Government [2014]

EWHC 1213 (Admin). 
decide which is the dominant policy", ${ }^{[8]}$ but, crucially, although this is a matter for their reasonable planning judgment, that judgment must be guided by the NPPF. "The closer the policies in the plan to the policies in the framework... the greater the weight they may be given", ${ }^{[9]}$ and again, the NPPF, "can and does provide advice to the decision makers about a number of matters, including the weight they might choose to put on various considerations". ${ }^{[10]}$

Thus, the weight to be given to the local plan can be dictated (subject to reasonable judgment) by the NPPF. Contrast this approach with that of the Court of Appeal in $R$ (Hampton Bishop PC) $v$ Herefordshire Council:

Whilst it is clear from other passages that the policies in the NPPF may affect the weight to be given to policies in the development plan, the duty to determine applications in accordance with the development plan unless material considerations indicate otherwise remains the same. ${ }^{[11]}$

Once again, the underlying doubt as to the practical, if not the legal, hierarchy between the local plan and the NPPF is producing a body of case law which although not directly contradictory, contains subtly different instructions to a planning authority, and which when brought together demonstrates that the presumption in section 38 is not satisfactory in its interpretation.

Local policy can be overridden therefore where the NPPF dictates that little weight be given to that policy. This is, although not in direct contradiction with section 38 , certainly a limitation on the strength of the presumption in favour of the local plan. For example, in Sayers $v$ South Hams DC ${ }^{[2]}$ Kirkbridge reasons that the "golden thread" of sustainable development and local needs must be balanced, and where possible, a 'win-win' is the preferred outcome. ${ }^{[13]}$ The "golden thread" however is also trying to mandate the adoption of a certain approach, and the 'balancing obligation' expressed in Sayers ${ }^{[14]}$ clashes with the prescriptive approach expressed in Tewkesbury BC v Secretary of State for Communities and Local Government. ${ }^{[15]}$ The reasoning in this case demonstrates very clearly that national guidance will, through the various means by which it imposes itself upon a local decisionmaker, unless there is a very significant and specific local factor to dictate a different approach, triumph. The scales are tipped in favour of the national guidance even though there is a "double-strength" presumption in favour of local plans ${ }^{[16]}$ Indeterminacy in localism, as a policy and as an ethos underpinning an approach to planning, produces indeterminacy in practice.

\section{Presumption in favour of sustainable development}

The key factor that tips the balance is the presumption in favour of sustainable development (United Kingdom, 2012b [14]). The need to satisfy the requirements of the presumption in favour of sustainable development is imposed onto local planning authorities at both the decision-making and the plan-making stage (United Kingdom, 2012b [15]). The meaning to

\footnotetext{
${ }^{[8]}$ Chase Milton Energy Ltd v Secretary of State for Communities and Local Government [2014] EWHC 1213 (Admin) at [35].

${ }^{[9]}$ Chase Milton Energy Ltd v Secretary of State for Communities and Local Government [2014] EWHC 1213 (Admin) at [11].

${ }^{[10]}$ Chase Milton Energy Ltd v Secretary of State for Communities and Local Government [2014] EWHC 1213 (Admin) at [10].

${ }^{[11]} R$ (Hampton Bishop PC) v Herefordshire Council [2014] EWCA Civ 878 at [30]

${ }^{[12]}$ Sayers $v$ South Hams DC [2013] PAD 39.

${ }^{[13]}$ Sayers v South Hams DC [2013] PAD 39 at [54].

${ }^{[14]}$ Sayers $v$ South Hams DC [2013] PAD 39

[15] Tewkesbury BC v Secretary of State for Communities and Local Government [2013] EWHC 286 (Admin) at [64-65].

${ }^{[16]}$ See $R$ (on the application of Sienkiewicz) v South Somerset DC [2013] EWHC 4090 (Admin) at [28].
} 
be given to sustainable development is to be taken from the NPPF as a whole (United Kingdom, 2012b [6]). Sustainable development, is, in effect, conflated with compliance with the national guidance. The courts have been unwilling to commit to a 'judicial' definition of sustainable development, but rather turn to the NPPF itself. As Collins J states in Scrivens $v$ Secretary of State for Communities and Local Government ${ }^{[17]}$ when invited to provide a definition of sustainable development: "I do not think that it is desirable that I should attempt to do that. What is sustainable in any particular circumstance will depend on a number of material factors". ${ }^{[18]}$ This hardly represents a clear and coherent definition of such an important core concept in English planning, especially when it is borne in mind that the courts have given themselves the function of determining the objective meaning of planning guidance, and therefore of the NPPF. ${ }^{[19]}$

The legal status of this requirement is complex: it is both a material consideration in a planning decision justifying departure from a local plan, ${ }^{[20]}$ and a consideration which will go into the drafting of that plan. As Bird (2013, p. OP86) highlights, to date the presumption has been treated as a very weighty material consideration, and not as a true presumption, and is therefore a question "of balance rather than [being] capable of objective testing". Nevertheless, a local plan which does not include or comply with the presumption in favour of sustainable development is likely to be considered unsound by the Planning Inspectorate. Although a balance is certainly required, there is a degree of "threshold" compliance which is likely to be needed.

The justiciability of the presumption in favour of sustainable development in individual planning decisions has manifested itself in a number of ways. For example in Enodis Property Developments Ltd and Enodis Ltd v Uttlesford $D C^{[21]}$ the development was rejected because it would not constitute sustainable development. The presumption was directly applicable. What is most clear however is that the courts are taking seriously the instruction in the NPPF that the meaning of sustainable development is to be based upon the entirety of the NPPF (United Kingdom, 2012b [6]). However, the general planning law principle that the meaning of a policy is a question of law to be determined by the courts remains intact as in Baker v South Downs National Park Authority. ${ }^{[22]}$

This means that, in effect, the presumption is not a presumption in favour of sustainable development as such, but rather a presumption in favour of NPPF-compliant proposals (Newark \& Sherwood DC v Philip Rare ${ }^{[23]}$ ). In Reliant Building Contracts v Nuneaton \& Bedworth $B C^{[24]}$ too Gregory invokes the presumption in favour of sustainable development, both as a reason to depart from a local plan, and as a reason for the inclusion of conditions as part of a permission. ${ }^{[25]}$ It is also part and parcel of the interpretation of what a local plan actually says, and the general terminology as to what sustainable development means will influence the interpretation of the more precise provisions of the NPPF, just as the specific content of the NPPF will influence those general terms.

In short, the treatment of the term is highly complex. Thankfully, the courts are not shying away from this complexity. The decision in Jimmy Cash $v$ Three Rivers $D C^{[26]}$ and the related

${ }^{[17]}$ Scrivens $v$ Secretary of State for Communities and Local Government [2013] EWHC 3549 (Admin).

${ }^{[18]}$ Scrivens $v$ Secretary of State for Communities and Local Government [2013] EWHC 3549 (Admin) at [15].

${ }^{[19]}$ Tesco Stores v Dundee City Council [2012] UK SC 13.

${ }^{[20]}$ Planning and Compulsory Purchase Act 2004, section 38(6).

${ }^{[21]}$ Enodis Property Developments Ltd and Enodis Ltd v Uttlesford DC [2013] PAD 55.

${ }^{[22]}$ Baker v South Downs National Park Authority [2013] PAD 3 at [34].

${ }^{[23]}$ Newark \& Sherwood DC v Philip Rare [2013] PAD 24.

${ }^{[24]}$ Reliant Building Contracts v Nuneaton \& Bedworth BC [2013] PAD 36.

${ }^{[25]}$ Reliant Building Contracts v Nuneaton \& Bedworth BC [2013] PAD 36 at [33]-[37].

[26] Jimmy Cash v Three Rivers DC [2012] PAD 40 at [45]. 
decisions of the courts in $R$. (on the application of Cash) $v$ Secretary of State for Communities and Local Government ${ }^{[27]}$ and Cash $v$ Secretary of State for Communities and Local Government ${ }^{[28]}$ show that the court will consider the delicate balance that a planning decisionmaker must strike in handling this complexity. So far, in that sense, so good. But there is a serious problem. The problem is at the heart of the presumption. The status of the presumption, in formal terms, is a material consideration which can justify the departure from a local development document as shown. So in Energiekontor UK Ltd v East Lindsey DC ${ }^{[29]}$ the conflict with the local plan and the development is overcome thanks to the presumption in favour of sustainable development. ${ }^{[30]}$ However, the 'material-ness' of national policy underplays what the presumption as a presumption must mean. This is because the presumption will not be a 'background assumption', but also an active participant at all stages in a decision-making process. Through its impact upon interpretation of both the local development plan and the wider NPPF itself, the presumption will have a 'silent' as well as an explicit effect.

What is somewhat bizarre is that the outcome of the balance process which emerges from this complex position may have the consequence that: "it is entirely possible that developments which could not on any objective assessment be described as "sustainable" are nonetheless identified as such for the purposes of the NPPF" (Bird 2013, p. OP86). Thus, there are two difficulties with the presumption in favour of sustainable development.

Firstly, there is the obvious incoherence that sustainable development is treated not as an independently identifiable criterion upon which to base a decision, but instead as shorthand for national policy as a whole. Secondly, there is the difficulty of treating a presumption as only a consideration that forms part of a decision. The presumption will have impacts at multiple stages of a decision, something which is hidden by simply referring to it as a 'material consideration'. This example therefore demonstrates the practical consequences of the theoretical concern over the incoherence concealed beneath the surface of core planning concepts ('material consideration', 'localism', 'sustainable development'), the competition between ideologies within planning policy ('sustainable development' as shorthand for national policy as a whole, with all the competing agendas enshrined therein), and the appropriate space and scale of planning (tension between localism and the 'presumption in favour of sustainable development' in national planning policy).

\section{Bringing the obligations together - incoherence and incompatibility}

These obligations raise two distinct problems. Firstly, the way the obligations are structured results in an attempt to confer onto local decision-makers autonomy and control, whilst at the same time restricting and directing that autonomy (Fox Strategic Land and Property $v$ Cheshire East Council ${ }^{[31]}$ ). National guidance will, in the end, triumph over local autonomy where that "autonomy" is not used to achieve the outcome desired.

More seriously, when these obligations are brought together, there is not just incoherence in the degree of autonomy and the process by which that autonomy is granted, but also in the structure of these obligations as a whole.

The reason for this is the status of the presumption in favour of the local plan and the presumption in favour of sustainable development. In most instances, the 'presumptions' will

${ }^{[27]} R$. (on the application of Cash) $v$ Secretary of State for Communities and Local Government [2013] EWHC 2028.

${ }^{[28]}$ Cash v Secretary of State for Communities and Local Government [2012] EWHC 2908 (Admin).

${ }^{[29]}$ Energiekontor UK Ltd v East Lindsey DC [2013] P.A.D. 37.

${ }^{[30]}$ Energiekontor UK Ltd $v$ East Lindsey DC [2013] P.A.D. 37 at [84].

${ }^{[31]}$ Fox Strategic Land and Property v Cheshire East Council ${ }^{[31]}$ [2014] P.A.D. 4 at [45]. 
be mutually reinforcing. In some cases however they will directly conflict. This can occur in two scenarios. Firstly, conflict can occur in the transitional period whilst we await the drafting and acceptance of NPPF-compliant local plans. Until that time, although there is a presumption in favour of the local plan, the fact that the plan is, policy-wise, out of date, will itself be a material consideration to justify rebutting the presumption in favour of the local plan. Such a situation is muddled, but it is in many ways simply reflective of the transition time required for local planning authorities to draft policy in accordance with the NPPF.

Temporary conflict is therefore, arguably, acceptable. It is however less easy to accept the 'final' legal position. There are multiple stages to the process which might result in a direct clash between these presumptions. Firstly, the local plan must pass through the Planning Inspectorate. In order to do so, it must be demonstrated that the local development plan meets the requirements of section 19 PCPA 2004. This demands that the local authority 'have regard to' national policy. For the most part, this 'regard' will result in the local plan and national policy being in step. What it does not mean, however, is that the local plan must comply with the NPPF. Rather, the local authority will be able to justify departures from national policy if they can show good reasons for doing so. It is in this situation when conflict will begin to emerge.

There are a number of options for challenging a development management decision made in these circumstances which (as it presumptively ought to) complies with the local plan. Firstly, the local plan itself can be challenged. Passing the investigation of the Planning Inspectorate does not mean that a plan would survive judicial review. ${ }^{[32]}$ The court may remit the plan for further consideration by the decision-maker and require that a particular planning decision be made, most likely, in accordance with the NPPF in the meantime.

Secondly, it would be possible to challenge a particular decision on the grounds that it did not comply with the NPPF notwithstanding compliance with the local plan. Here, the court has to make a choice. Was the decision-maker reasonable in relying on the local plan, or not? The plan will have been found sound by the Planning Inspectorate and so at one level the departure from national policy has already been found to be justified. Thus, the court may also be convinced by the reasons that convinced the Planning Inspectorate for this departure, not only in general terms in terms of the validity of the local plan, but also in specific terms in relation to the particular decision. On the other hand, they may not be so convinced. They may consider that not to rely on the national policy in the specific case was unreasonable, or a failure to take account of a material consideration, notwithstanding the presumption in favour of the local plan. Such an approach is in evidence in St Albans CC and DC v Hunston Properties Ltd, where the court states that:

It would, in my judgment, be irrational to say that one took account of the constraints embodied in the polices in the Framework, such as Green Belt, when preparing the local plan, as para.47(1) clearly intends, and yet to require a decision-maker to close his or her eyes to the existence of those constraints when making a development control decision. ${ }^{[33]}$

Thus the NPPF policy is relevant of course to the drafting of the local plan, but also when considering the local plan it must be taken into account again in relation to a specific development, even if the local plan itself is already confirmed to be compliant with the NPPF. The NPPF can assert its weight even over a compliant local document.

This comes about thanks to the fact that the content of the NPPF is deemed to be the definition of sustainable development. Thus development which complies with the NPPF is sustainable, and therefore there is a presumption in favour of NPPF-compliant development. This presumption, if not exactly mirrored in the local plan, will leave the court with a choice

${ }^{[32]}$ Zurich Assurance v Winchester City [2014] EWHC 758 (Admin).

${ }^{[33]}$ St Albans CC and DC v Hunston Properties Ltd [2013] EWCA Civ 1610 at [30]. 
between the local plan, which is presumptive, and the NPPF, which on its own terms is also presumptive. In weighing this balance the court is limited as to how to resolve any tensions. The review of the local decision is to be based on the standard of judicial review, not on the standard of correctness: 'reasonableness' is the watchword. This might help the court to balance its way out of the muddle, whatever the underlying incoherence. The meaning of policy however is ultimately a question of law, and for the courts to determine. This gives them a double responsibility. Firstly, they may choose to interpret the local plan differently from the local decision-maker so as to artificially or otherwise bring it into line with the NPPF. An alternative tactic would be, in determining the meaning of the NPPF, to conclude that the local decision has failed to properly understand the NPPF, and therefore sustainable development, and that therefore it has a fatal flaw. Both routes fail to grapple with the conflict between local plan and NPPF per se, even if the end result is the same. Importantly, this process reveals the incoherence and incompatibility which may arise from planning policy containing loosely defined core concepts, competing ideologies and tensions over the appropriate space and scale of planning, while at the same time appearing to conceal it again through the exertion of the interpretative power of the law in single decisions. However, when taken together, the incompatibility of these individual decisions can be seen to result in a legal framework which is itself incoherent.

A more explicit approach would be for the court to admit the conflict and to then conclude that the existence of the conflict, which is itself a material consideration, plus the material consideration of the content of the NPPF, which is presumptive, outweighs the local plan. This can happen even though the plan was considered sound and justified in accordance with section 19. The court could conclude that the plan does not justify the particular decision because the reasons which are used justify the departure for the NPPF do not apply in an instant case. In so doing, the court would be giving greater weight to the presumption in favour of sustainable development than the presumption in favour of the local plan. Balancing presumptions is a route to incoherence.

Even in a planning context where presumptions are treated as very weighty reasons for a decision, the essence of a presumption is that in the absence of evidence, a decision in compliance with the presumption will be justified. To take a hypothetical case, faced with a local plan, the NPPF, a planning proposal, and very little evidence as to the likely effect of development, the local decision maker has no reasons to justify departing from the local plan. Similarly, they have no reason to depart from the presumption in favour of sustainable development. There is nothing to "weigh" the presumptions against, and this is why presumptions, even when treated as weighty reasons, are more than that. They are a way of making a decision in the face of a lack of evidence. When there are two directly competing presumptions, a lack of evidence will prevent the decision-maker from legitimately following one or the other.

The result of this is that the local decision-maker is required to reconcile the irreconcilable. Strategic thinking and forward planning will be stifled by the impossibility of actually complying with these legal obligations, and local development plan documents will therefore be vulnerable to judicial review. This problem is more than a difficulty in drafting policy. Certainly that is a valid criticism of the somewhat contradictory ethos of localism. But it is a more fundamental problem arising from the legal mechanism used to attempt to achieve these ends. The local decision-making process which forms a fundamental part of the philosophy of localism - consultation at a local level, and local determination of issues - makes meeting the requirement of achieving effective sustainable development very difficult. Map these difficulties onto the two levels of decision-making - the drafting of local plans, and the making of individual development management decisions - and the underlying semantic, ideological and scale-based tensions in planning can no longer be hidden by references to balance and reasonableness. The NPPF fails to commit to any underlying conceptual basis and therefore fails to understand the legal underpinning required to allow these new 
obligations to operate. The result: incoherence, incompatibility and inconsistency, and a major headache for local planning authorities.

\section{Conclusions}

Planning is arguably replete with incoherence - in the language used, in the ideologies internal to it, and at the spaces and scales at which it is designed to operate. Underlying disagreements are concealed by policy statements referring to balance and reasonableness. But when such policy must be considered in a judicial fora, becoming in the process justiciable and therefore crystallised into law, incoherence re-emerges.

Deep-rooted theoretical problems within planning can be seen as purely 'academic' with no practical implication. Planning policy is broadly drafted, especially at a national level, and individual decision-makers are relied upon to reach sensible and practical decisions which achieve 'reasonable' outcomes. In such a context perhaps an underlying lack of commitment to understandings of core concepts, or as to the appropriate balance of power within a state, could be said not to matter. They do matter however, and they matter because once policy is brought down to an individual decision, in almost all cases a prioritisation must be made localism, or sustainable development; autonomy or prescription, and this prioritisation is made by local planning authorities, planning inspectors and the courts. In so-doing, they must interpret the terms of policy and legislation. They must fix the meanings of ambiguous concepts, in so doing prioritising one of the competing ideologies enshrined in planning policy, and they must allocate power of decision-making to one authority over another. This paper has focused on this process at the judicial level, but it is equally likely to occur at local level even before judicial review through the 'contested' deliberative processes and 'crystallising' decision-making pertaining to the local plan making and development management functions of local planning authorities.

Incoherence in planning policy therefore produces incompatibility in the legal framework. In the English context this can be seen in reference to the legal mechanisms giving effect to the localism agenda and in the 'presumption' in favour of sustainable development. Both of these legal obligations are internally problematic, not least because they depend upon contested understandings of their central tenets. When brought together however, they are incompatible as legal obligations because they result in two parallel presumptions operating simultaneously. There is a presumption both in favour of a local decision, and in favour of sustainable development. In addition, the latter presumption is also central to the process of interpretation of the local development management decision. Without definition, and without commitment to an understanding of the language used, the ideologies behind them, and the spaces and scales on which governance should take place, we rely only on the skill of decision-makers to conceal this incoherence in reaching their ultimate decision. Such obfuscation may be practically useful, resulting in sensible individual decisions, but it also calls seriously into question the legitimacy of the collective regulatory framework and the power that it confers.

\section{References}

- Adshead, J. (2014), "Revisiting the ideologies of planning law: private property, public interest and public participation in the legal framework of England and Wales", International Journal of Law in the Built Environment, Vol. 6, pp. 174-193.

- Allmendinger, P. (2009), Planning Theory, 2nd Edition, Palgrave Macmillan, Basingstoke and New York.

- Allmendinger, P. and Haughton, G. (2009), "Soft spaces, fuzzy boundaries, and metagovernance: the new spatial planning in the Thames Gateway", Environment and Planning A, Vol. 41, pp. 617 - 633. 
- Allmendinger, P. and Haughton, G. (2010), "Spatial planning, devolution, and new planning spaces", Environment and Planning C, Vol. 28, pp. $803-818$.

- Allmedinger, P. and Haughton, G. (2011), "Challenging Localism". Town \& Country Planning, July/August 2011, pp. 314-318.

- Allmendinger, P. and Haughton, G. (2012), "Post-political spatial planning in England: a crisis of consensus?", Transactions of the Institute of British Geographers, Vol. 37, pp. 89-103.

- Allmendinger, P. Haughton, G. and Shepherd, E. (2014), "Where is planning to be found? Material practices and the multiple spaces of planning" - accepted for Association of European Schools of Planning, Utrecht 2014.

- Bird, S. (2013), “The NPPF in practice: panacea, pariah or placebo?” Journal of Planning and Environmental Law, Vol. 13 Supp, pp. OP82-99.

- Buser, M. and Farthing, S. (2011), "Spatial planning as an integrative mechanism: a study of sub-regional planning in south hampshire, England", Planning Practice \& Research, Vol. 26, pp. 307-324.

- Cochrane, A. (2003), "The new urban policy: towards empowerment or incorporation? The practice of urban policy", in Imrie, R. and Raco, M. (eds) Urban Renaissance? New Labour, community and urban policy, The Policy Press, Bristol, pp. 223-34.

- Conservative Party (2010), "Open source planning green paper", The Conservative Party, London.

- Davoudi, S. (2000), "Sustainability: a new vision for the British planning system", Planning Perspectives, Vol. 15, pp. 123 - 137.

- Fagence, M. (1983), "Ideological fundamentalism in town planning - an exploratory appraisal", The Environmentalist, Vol. 16, pp. 17 - 27.

- Foley, D.L. (1960), "British Town Planning: One Ideology or Three?", The British Journal of Sociology, Vol. 11, pp. $211-231$.

- Freeden, M. (1998), Ideologies and political theory: a conceptual approach [ebook] Oxford University Press, Oxford, available at Oxford Scholarship Online: http://www.oxfordscholarship.com/view/10.1093/019829414X.001.0001/acprof9780198294146 (accessed 18 July 2013).

- Furbey, R. (1999), "Urban "regeneration": reflections on a metaphor", Critical Social Policy, Vol. 19, pp. $419-45$.

- Guttenberg, A.Z. (2009), "Planning and ideology", Journal of Planning History, Vol. 8, pp. 287-294.

- Haughton, G., Allmendinger, P. and Oosterlynck, S. (2013), "Spaces of neoliberal experimentation: soft spaces, postpolitics, and neoliberal governmentality", Environment and Planning A, Vol. 45, pp. 217 - 234.

- Hickson, K. (2013), "The localist turn in British politics and its critics", Policy Studies, Vol. 34, pp. $408-421$.

- HM Government (2010), "The Coalition: our programme for government", The Cabinet Office, London.

- House of Commons, (2011), "Localism: Third report of session 2010-12", The Stationary Office Limited, London, available at www.publications.parliament.uk/pa/cm201012/cmselect/cmcomloc/547/547.pdf (accessed 20 March 2014]).

- Layard, A. (2012), "The Localism Act 2011: what is "local" and how do we (legally) construct it?", Environmental Law Review, Vol. 14, pp. 134-144.

- Lees, E. (2014) "Localism and environmental law: uneasy bedfellows?" Journal of Planning and Environmental Law, Vol. 2, pp. 176-180.

- MacLeod, G. and Goodwin, M. (1999), "Space, scale and state strategy: rethinking urban and regional governance", Progress in Human Geography, Vol. 23, pp. 503 - 527.

- McAuslan, P. (1980), The Ideologies of Planning Law, Pergamon, London. 
- Reade, E. (1983), "If planning is anything, maybe it can be identified?", Urban Studies, Vol. 20, pp. 159-171.

- Rittel, H.W.J. \& Webber, M.M. (1973), "Dilemmas in a general theory of planning", Policy Sciences, Vol. 4, pp. 155-169.

- Stead, D. and Meijers, E. (2009), "Spatial planning and policy integration: concepts, facilitators and inhibitors", Planning Theory and Practice, Vol. 10, pp. 317 - 332.

- Taylor, N. (1980), "Planning theory and the philosophy of planning", Urban Studies, Vol. 17, pp. 159-172.

- Taylor, N. (2003), "More or less meaningful concepts in planning theory (and how to make them more meaningful): A plea for conceptual analysis and precision: An essay in memory of Eric Reade: 1931-2002", Planning Theory, Vol.s 2, pp. 91-100.

- Taylor, M. (2013), "Can the NPPF crack the housing crisis?" Journal of Planning and Environmental Law, Vol. 13 Supp, OP7-17.

- Tewdwr-Jones M. (1999), "Discretion, flexibility, and certainty in British planning: emerging ideological conflicts and inherent political tensions", Journal of Planning Education and Research, Vol. 18, pp. $244-256$.

- United Kingdom (2012a), DCLG, "Making the planning system work more efficiently and effectively" available at https://www.gov.uk/government/policies/making-theplanning-system-work-more-efficiently-and-effectively (accessed 1st November 2013).

- United Kingdom (2012b), DCLG, "National Planning Policy Framework", DCLG, London.

- United Kingdom (2012c), DEFRA, "An overview of the Local Nature Partnership role", DEFRA, London.

- United Kingdom (2013), DEFRA, "Policy - Making sustainable development a part of all government policy and operations" available at https://www.gov.uk/government/policies/making-sustainable-development-a-part-of-allgovernment-policy-and-operations (accessed 11th March 2014).

- United Kingdom (2014), DCLG, "Planning Practice Guidance", available at http://planningguidance.planningportal.gov.uk (accessed 10 March 2014).

- United Kingdom (2014b), Cabinet Office, "Red Tape Challenge", available at https://www.redtapechallenge.cabinetoffice.gov.uk/home/index/ (accessed 13th March 2014). 